\title{
Research on the Relationship between Psychological Capital, Knowledge Sharing and Innovation Behavior of Logistics Enterprises Employees
}

\author{
Bo Dong ${ }^{1,}$, Xi-fu Wang and Ying Ding \\ ${ }^{1}$ School of Traffic and Transportation, Beijing Jiaotong University, Beijing 100080, China. \\ a328550338@qq.com
}

Keywords: innovation behavior, psychological capital, knowledge sharing.

\begin{abstract}
To sort and review the study on psychological capital, knowledge sharing, innovative behavior and the relationship among them, and on this basis put forward hypotheses, this article selected Logistics Enterprises employees as a sample, questionnaires were issued mainly R \& D personnel, a total of 117 questionnaires and 101 copies were returned. Then the questionnaire data were described by statistical analysis, reliability and validity analysis, correlation and regression analysis, and ultimately concluded that: (1)Logistics Enterprises employees' psychological capital on knowledge sharing have a positive impact on innovation behavior ; (2) Logistics Enterprises employees' knowledge sharing has a positive impact on innovation behavior (3) Logistics Enterprises employees' knowledge sharing plays an intermediary role between psychological capital and innovation behavior . Finally, the present study has some shortcomings, the data of this paper is very limited, and to explore the variables are the staff level, and the relationship of the organizational level still unknown, as research continues, hoping that above problems can be effectively solved in the future.
\end{abstract}

\section{Introduction}

From an organizational point, organizational innovation atmosphere has a great influence on employees' innovative behavior. Organizational innovation atmosphere is positive, the staff will actively innovate, management innovation behavior for failure will not make a serious punishment. Construction of the organizational innovation atmosphere is driven by individual employees' excellent expression. From a personal point, the individual's psychological traits and knowledge acquisition are important antecedents of innovative behavior. Foreign studies have shown that, among members of the organization to share knowledge, well-structured atmosphere for innovation can drive innovation behavior, the personal qualities of employees with knowledge to share more and more, companies also derive tremendous economic benefits. Then, explore the important issue of how to make employees are more willing to share knowledge to become a focal spot to research scholars. Eventually found that positive psychological capital as an individual psychological factor, can promote employees' knowledge sharing, thereby enhancing innovative behavior. Therefore, how to correctly guide the mental state of employees, enhance the innovative behavior of employees has become the focus attention of scholars.

This study attempts to study these issues. Specifically, Take Logistics Enterprises as the research company, verify the relationship between employees' psychological capital and employees' innovative behavior, knowledge sharing as a communication bridge between the two issues.

\section{Literature Review}

\section{(1) Innovation Behavior and influencing factors}

West and Farr (1989) defined innovation behavior that a role in the enterprise employees, in order to enhance the performance of the individual or organizational performance, the creation of new ideas, presentations and applications. Scott and Bruce (1994) put forward that innovation behavior is complexly consists of three different actions constituted, namely problem identification, 
ideas and innovative ideas to enhance implementation. Zhou and George (2001) also believes that staff innovative behavior not only includes the generation of innovative ideas, but also should include the promotion and realization of the idea. Kleysen and Street (2001) by reading the literature on innovative behavioral research, summed up five stage innovation behavior include: looking for opportunities to generate ideas, the formation of investigation, support, applications.

Dimensions on innovative behavior, different people have different views. Scott and Bruce (1994) considered from three dimensional measurements, (1) namely recognition and vision generate problems; (2) to extend the idea of extension; (3) implementation of innovative ideas. The Kleysen and Street (2001) more detailed breakdown of these three dimensions, turning it into five dimensions: look for opportunities, to generate ideas, the formation of investigation, support, applications. Our researchers Huangzhi Kai (2004) according to the domestic situation, which is divided into two dimensions: the idea generation and idea execution. In this paper, adopt to generally accepted Scott and Bruce development scale.

(2) psychological capital and influencing factors

Psychological capital, refers to the individual manifested a positive state of mind, it is a psychological element of human capital and social capital beyond, is to help personal growth and performance improvement of the mental element. The concept of psychological capital is developed on the basis of positive psychology and positive organizational behavior on arising, Luthans et al in 2002 first proposed the concept of "psychological capital", they thought psychological capital is an issue which can be able to have a positive effect on the mind. From a personal point of view, psychological capital can enhance the individual's work performance; From an organizational point, the role of psychological capital beyond the human capital and social capital can enhance their competitive advantage.

Psychological capital is a new concept, it has been changed in the development and measurement, Luthans 24 projects proposed by the composition of the scale, with good convergent validity, in this psychological capital is divided into four dimensions: self-efficacy, optimism, toughness, hope. About the choice of scale, only the reliability and validity of the PCQ-24 has been verified, this article intends to adopt Luthans the PCQ-24 scale, and the psychological capital is divided into two dimensions: self-efficacy and hope.

\section{(3) knowledge sharing and influencing factors}

Mclure Wasko and Faraj (2000) defined it as the sharing of personal knowledge about the learning process and generating new knowledge. Davenport and Prusak put forward that knowledge sharing is a knowledge market trading, buyers and sellers when the parties feel good from the exchange, they will exchange knowledge.

Academics from three general perspective willingness to share knowledge: technical perspective, the perspective of economic and social psychological perspective. Technical perspective is the study of communication technology on the employees' knowledge sharing incentives, from an economic perspective is to measure the costs and benefits expected to share knowledge, psychological perspective affected their perception of care staff. Comprehensive proposal of many scholars, this paper from Kalling and Styhre (2003) study of the scale.

\section{Models and Hypothesis}

\section{(1) Theoretical Model}

In this paper, the theoretical model shown in Figure 1, the main purpose of this study was to investigate the psychological capital and innovative behavior of staff relations, employees' knowledge sharing as an intermediary variable. 
Hl

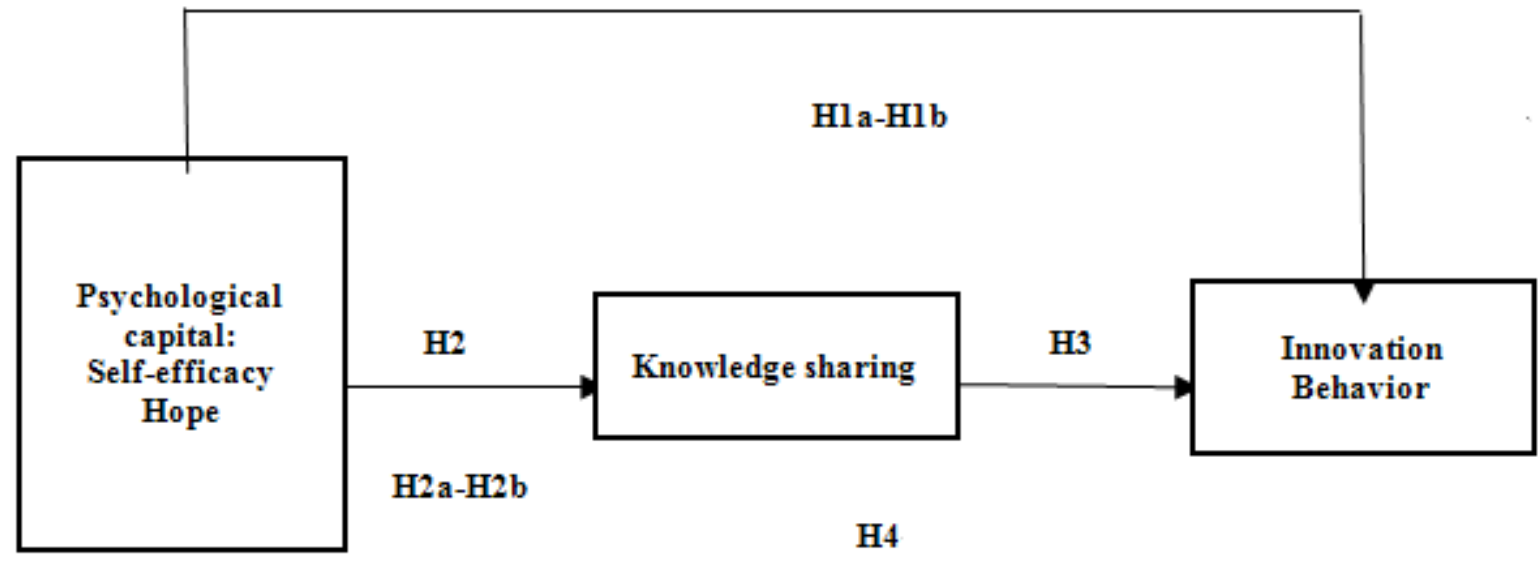

Fig. 1 Psychological Capital, Knowledge Sharing and Innovation Behavior Models

\section{(2) Hypothesis}

H1: Logistics Enterprises employees' psychological capital has a positive effect on innovation behavior

H1a: Logistics Enterprises employees' self-efficacy has a positive impact on the innovative behavior

H1b: Logistics Enterprises employees' hope has a positive impact on innovation behavior

H2: Logistics Enterprises employees' psychological capital has a positive impact on knowledge sharing

H2a: Logistics Enterprises employees' self-efficacy has a positive impact on knowledge sharing

H2b: Logistics Enterprises employees' hope has a positive impact on knowledge sharing

H3: Logistics Enterprises employees' knowledge sharing has a positive impact on the innovative behavior

H4: Logistics Enterprises employees' knowledge sharing plays an intermediary role between psychological capital and innovative behavior

\section{Research Methods}

According to the study objectives and the need for testing hypotheses, this research use SPSS17.0 to describe data about descriptive statistics, reliability analysis, validity analysis, correlation analysis and regression analysis.

\section{(1) Descriptive Statistics}

Descriptive statistical analysis is essential before the situation analysis of specific analysis to calculate the frequency and variable frequency by analyzing the pattern set, the degree of dispersion and distribution of data.

\section{(2) Reliability Analysis}

Reliability refers to the internal consistency between the questions of scale, in general, the more similar scale answer to the question, the higher the reliability scale is. Research Cronbach's $\alpha$ mainly used to indicate the correlation coefficient, the greater the value of $\alpha$, indicating the consistency of the scale of the problem as possible, the minimum acceptable value of $\alpha$ is 0.5 .

\section{(3) Validity Analysis}

Validity is used to measure the effectiveness of the measure, the higher the value of the validity of the measurement results can reflect the real situation of the study.

\section{(4) Correlation analysis}

Correlation main measure of correlation between variables, using Pearson coefficients general description. Objective correlation analysis conducted in this study is to verify if the psychological capital, knowledge sharing is relevant, and the degree of correlation between the level of innovative behavior. Correlation analysis only a simple description of the relationship between the various 
variables, for which the internal mechanism of action does not expressly stated.

\section{(5) Regression Analysis}

Regression analysis is based on the correlation analysis, analysis method to explore the variables inherent causality. Including: modeling, parameter estimation step 4, test model, the use of models. In the test of the model to be used $t$ test, $F$ test and $R^{2}$ test, $t$ test is mainly to verify whether a valid regression, $\mathrm{F}$ test was used to test the significance of the regression equation, $\mathrm{R}^{2}$ test was used to describe the independent variables and the dependent variable degree of correlation.

\section{Data Analysis}

\section{(1) Reliability and Validity Analysis}

TABLE 1 Reliability Psychological Capital Scale Analysis

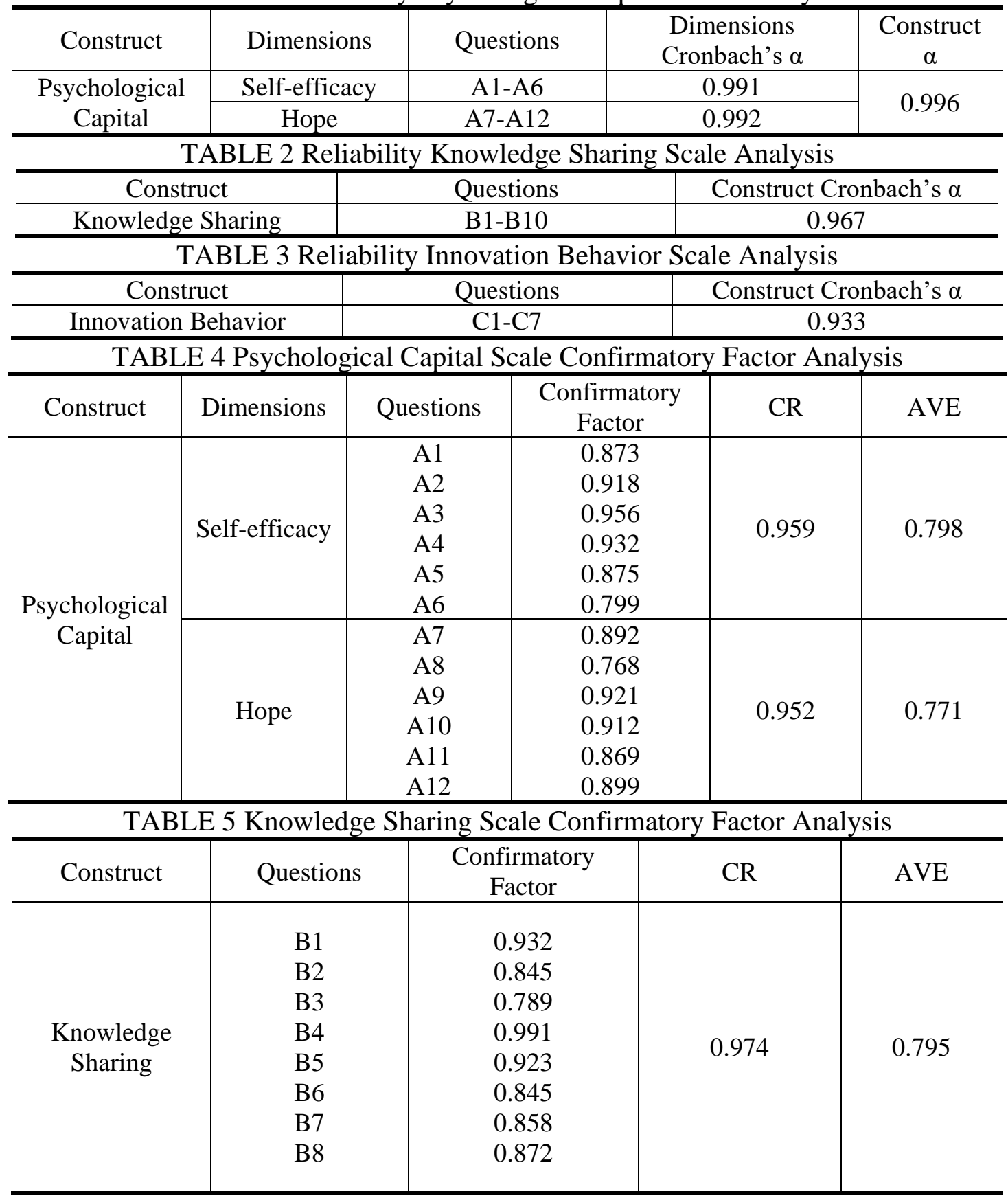


TABLE 6 Innovation Behavior Scale Confirmatory Factor Analysis

\begin{tabular}{|c|c|c|c|c|c|}
\hline Construct & Questions & \multicolumn{2}{|c|}{$\begin{array}{c}\text { Confirmatory } \\
\text { Factor } \\
\end{array}$} & CR & AVE \\
\hline \multirow[t]{2}{*}{$\begin{array}{c}\text { Innovation } \\
\text { Behavior }\end{array}$} & $\begin{array}{l}\text { C1 } \\
\text { C2 } \\
\text { C3 } \\
\text { C4 } \\
\text { C5 } \\
\text { C6 } \\
\text { C7 }\end{array}$ & & $\begin{array}{l}.871 \\
.919 \\
.936 \\
.762 \\
.923 \\
.918 \\
.866\end{array}$ & 0.962 & 0.786 \\
\hline & AVE & $\begin{array}{l}\text { Standard } \\
\text { deviation }\end{array}$ & $\begin{array}{c}\text { Psychological } \\
\text { Capita }\end{array}$ & $\begin{array}{c}\text { Knowledge } \\
\text { Sharing }\end{array}$ & $\begin{array}{c}\text { Innovation } \\
\text { Behavior }\end{array}$ \\
\hline $\begin{array}{l}\text { Psychological } \\
\text { Capita } \\
\end{array}$ & 3.30 & 1.63 & 0.865 & & \\
\hline $\begin{array}{c}\text { Knowledge } \\
\text { Sharing }\end{array}$ & 3.33 & 1.67 & $0.545^{* *}$ & 0.892 & \\
\hline $\begin{array}{l}\text { Innovation } \\
\text { Behavior }\end{array}$ & 3.23 & 1.54 & $0.755^{* *}$ & $0.812^{* *}$ & 0.886 \\
\hline
\end{tabular}

Denote at the 0.01 significance level was significantly associated

(2) Correlation and Regression Analysis

TABLE 8 Correlation Analysis of Psychological Capital and Innovative Behavior

\begin{tabular}{c|c|c|c}
\hline & $\begin{array}{c}\text { Psychological } \\
\text { Capital }\end{array}$ & Self-efficacy & Hope \\
\hline Innovative Behavior & $0.755^{* *}$ & $0.786^{* *}$ & $0.732^{* *}$ \\
\hline \multicolumn{2}{c}{ TABLE 9 Correlation Analysis of Psychological Capital and Knowledge Sharing } \\
\hline & $\begin{array}{c}\text { Psychological } \\
\text { Capital }\end{array}$ & Self-efficacy & Hope \\
\hline Knowledge Sharing & $0.545^{* *}$ & $0.612^{* *}$ & $0.509^{* *}$ \\
\hline TABLE 10 Correlation Analysis of Knowledge Sharing and Innovative Behavior \\
\hline \multicolumn{2}{c}{ Knowledge Sharing } \\
\hline \multicolumn{2}{c}{$0.812^{* *}$} \\
\hline
\end{tabular}

TABLE 11 Regression Analysis of Psychological Capital and Innovative Behavior

\begin{tabular}{|c|c|c|c|c|c|c|c|}
\hline \multirow[t]{2}{*}{ Model } & \multicolumn{2}{|c|}{$\begin{array}{l}\text { Non-standardi } \\
\text { zed } \\
\text { coefficients }\end{array}$} & $\begin{array}{c}\text { Standardized } \\
\text { coefficients }\end{array}$ & \multirow[t]{2}{*}{$\mathrm{T}$} & \multirow[t]{2}{*}{ Sig. } & \multirow[t]{2}{*}{ Adj. $R^{2}$} & \multirow[t]{2}{*}{$F$} \\
\hline & B & $\begin{array}{l}\text { Standar } \\
\text { d error }\end{array}$ & Beta & & & & \\
\hline $\begin{array}{c}\text { Constant } \\
\text { Psychologica } \\
\text { l Capital }\end{array}$ & $\begin{array}{c}0.65 \\
6 \\
0.82 \\
1\end{array}$ & $\begin{array}{l}0.309 \\
0.012\end{array}$ & 0.711 & $\begin{array}{c}1.909 \\
11.541\end{array}$ & $\begin{array}{l}0.021 \\
0.000\end{array}$ & 0.327 & $\begin{array}{c}120.591 \\
* *\end{array}$ \\
\hline
\end{tabular}

TABLE 12 Regression Analysis of Psychological Capital and Knowledge Sharing

\begin{tabular}{|c|c|c|c|c|c|c|c|}
\hline \multirow{2}{*}{ Model } & \multicolumn{2}{|c|}{$\begin{array}{c}\text { Non-standardized } \\
\text { coefficients }\end{array}$} & $\begin{array}{c}\text { Standardized } \\
\text { coefficients }\end{array}$ & \multirow{2}{*}{$\mathrm{T}$} & \multirow{2}{*}{ Sig. } & \multirow{2}{*}{ Adj. $\mathrm{R}^{2}$} & \multirow{2}{*}{$\mathrm{F}$} \\
\hline & B & $\begin{array}{l}\text { Standar } \\
\text { d error }\end{array}$ & Beta & & & & \\
\hline $\begin{array}{l}\text { Constant } \\
\text { Psycholog }\end{array}$ & 0.528 & 0.216 & & 2.129 & 0.010 & & 156.291 \\
\hline $\begin{array}{c}\text { ical } \\
\text { Capital }\end{array}$ & 0.729 & 0.013 & 0.655 & 13.117 & 0.000 & 0.501 & $* *$ \\
\hline
\end{tabular}


TABLE 13 Regression Analysis of Knowledge Sharing and Innovative Behavior

\begin{tabular}{|c|c|c|c|c|c|c|c|}
\hline \multirow{2}{*}{ Model } & \multicolumn{2}{|c|}{$\begin{array}{l}\text { Non-standardize } \\
\text { d coefficients }\end{array}$} & $\begin{array}{c}\text { Standardized } \\
\text { coefficients }\end{array}$ & \multirow{2}{*}{$\mathrm{T}$} & \multirow{2}{*}{ Sig. } & \multirow{2}{*}{ Adj. $R^{2}$} & \multirow{2}{*}{$\mathrm{F}$} \\
\hline & B & $\begin{array}{l}\text { Standar } \\
\text { d error }\end{array}$ & Beta & & & & \\
\hline $\begin{array}{l}\text { Constant } \\
\text { Knowledge } \\
\text { Sharing }\end{array}$ & $\begin{array}{l}0.910 \\
0.412\end{array}$ & $\begin{array}{l}0.219 \\
0.334\end{array}$ & 0.739 & $\begin{array}{l}2.823 \\
9.311\end{array}$ & $\begin{array}{l}0.008 \\
0.000\end{array}$ & 0.691 & $\begin{array}{c}128.435 \\
* *\end{array}$ \\
\hline
\end{tabular}

TABLE 14 Regression Analysis of Mediating Role of Knowledge Sharing

\begin{tabular}{|c|c|c|c|c|}
\hline Regression No. & Argument & $\begin{array}{c}\text { The dependent } \\
\text { variable }\end{array}$ & $\begin{array}{l}\text { Regression } \\
\text { coefficients }\end{array}$ & Sig. \\
\hline 1 & $\begin{array}{c}\text { Psychological } \\
\text { Capital }\end{array}$ & $\begin{array}{c}\text { Innovative } \\
\text { Behavior }\end{array}$ & 0.711 & 0.000 \\
\hline 2 & $\begin{array}{l}\text { Psychological } \\
\text { Capital }\end{array}$ & $\begin{array}{l}\text { Knowledge } \\
\text { Sharing }\end{array}$ & 0.655 & 0.000 \\
\hline 3 & $\begin{array}{c}\text { Knowledge } \\
\text { Sharing }\end{array}$ & $\begin{array}{c}\text { Innovative } \\
\text { Behavior }\end{array}$ & 0.739 & 0.000 \\
\hline \multirow{2}{*}{4} & $\begin{array}{c}\text { Psychological } \\
\text { Capital }\end{array}$ & \multirow{2}{*}{$\begin{array}{l}\text { Innovative } \\
\text { Behavior }\end{array}$} & 0.672 & 0.041 \\
\hline & $\begin{array}{l}\text { Knowledge } \\
\text { Sharing }\end{array}$ & & 0.381 & 0.157 \\
\hline
\end{tabular}

\section{Conclusion}

Take Logistics Enterprises employees as the research objects, knowledge sharing as an intermediary role, to explore the relationship between psychological capital and innovative behavior, through hypothesis testing, get the following conclusions.

1) psychological capital has a positive impact on innovation behavior.

2) self-efficacy has a positive impact on innovation behavior.

3) Hope has a positive impact on innovation behavior.

4) psychological capital has a positive impact on knowledge sharing.

5) self-efficacy has a positive impact on knowledge sharing.

6) hope has a positive impact on knowledge sharing.

7) knowledge sharing has a positive impact on innovation behavior.

8) knowledge sharing plays an intermediary role between psychological capital and innovative behavior.

In theoretical research, academic research institutions affect the incentives mostly from organizations, few studies were studying from the perspective of the psychological of employees. In this study, statistical analysis regression analysis confirm the research hypotheses, the results show that positive psychological traits of the staff have a positive influence on innovative behavior .To conduct research in the field of innovation provides a theoretical value and contribution.

Among the practical management, Logistics Enterprises human resource management workers carrying out R \& D personnel recruitment, you can find some psychological traits associated personnel, in order to improve their ability to innovate. In the training, we should encourage them to share knowledge, develop innovative thinking to enhance the company's competitiveness references.

\section{References}

[1] Oldham, G.R.and Cummings, A. Employee creativity: Personal and contextual factors at work [J]. Academy of Management Journal, 1996, 39: 607-634.

[2] Van Maanen J, Schein E H. Toward a theory of organizational socialization [J]. Research in organizational behavior,1979, 1: 209-264. 
[3] Westerman J W, Cyr L A. An integrative analysis of person-organization fit theories [J]. International Journal of Selection and Assessment,2004,12, (3):252-261.

[4] Woodman R W, Sawyer J E, Griffin R W. Toward a theory of organizational creativity [J]. Academy of Management Review,1993,18, (2):293-321.

[5] Zhao Bin, Qingfeng, Li Xinjian, Psychological Impact of Science and Technology Capital on Innovation Behavior: knowledge Jobs Difficult to Adjust Variable [J]. Science and Management of Science and Technology, 2012,33: 175-180. 